\title{
An Evaluation of the Relationship between Service Quality in Primary Education and Parent Satisfaction
}

\author{
Gencay İncesu ${ }^{1} \&$ Barış Aşıkgil ${ }^{2}$ \\ ${ }^{1}$ Institute of Social Sciences, Okan University, İstanbul, Turkey \\ ${ }^{2}$ Department of Statistics, Mimar Sinan Fine Arts University, İstanbul, Turkey \\ Correspondence: Gencay İncesu, Institute of Social Sciences, Okan University, İstanbul, Turkey. Tel: \\ 90-532-792-8909. E-mail: gencay.incesu@sabah.com.tr
}

Received: June 1, 2012 Accepted: July 30, 2012 Online Published: September 16, 2012

doi:10.5539/ijbm.v7n18p92 URL: http://dx.doi.org/10.5539/ijbm.v7n18p92

\begin{abstract}
The education is not only a major sector nowadays, but it is also an investment by parents for their children. This study aims to investigate the effect of the dimensions (reliability, tangibility, responsiveness, assurance and empathy) of service quality in primary education on parent satisfaction. This research is conducted in a public primary school and self-administered questionnaire is used to collect the related data. Data is collected based on SERVQUAL model through distributing 400 questionnaires to randomly selected parents in Celal Avşar Primary School in Turkey. The results of this study show that the tangibility, the reliability, the assurance and the empathy of service quality are important dimensions and they have significant positive effect on parent satisfaction.
\end{abstract}

Keywords: parent satisfaction, primary education, service quality, SERVQUAL model

\section{Introduction}

Customer satisfaction is highly related to service quality and it is an important aspect for service organizations (Lee \& Hwan, 2005). To develop relationship with current customers and to magnetize new customers, many companies think that service quality has strategic importance (Ugboma et al., 2007). Customers are interested very much with the quality of received output. Positive perception on the quality of services being delivered occurs when it exceeds the customers' expectations (Anderson, Fornell, \& Lehmann, 1994). In primary education parents are one of the most important stakeholder and they make decision which school their children attend. School selection decisions and good school search behaviors of parents are affected by parental satisfaction. Parental satisfaction is tried to measure by many schools in order to find ways of improving the schools and to evaluate the quality of the education provided to children (Pederson \& Wilk, 1993). The usage of the most convenient measurement tool helps management to evaluate the service quality which is provided by their schools.

Primary education is the first and important stage of education in which academic basis is established. This paper focuses on a public school and this condition has two reasons. Firstly, public schools do not necessarily motivate themselves to create customer satisfaction. Secondly, the bureaucratic procedures faced during the fieldwork stage in the public school are too complex and time consuming. However, there are limited researches about effect of service quality on parent satisfaction. The focus on primary education can be considered as the contribution of this paper. This paper proceeds as follows. Section 2 and 3 give the literature review about parent satisfaction and service quality. Section 4 includes the framework and methodology of this research. Section 5 gives the findings and discussion. Section 6 is the conclusion.

\section{Parent Satisfaction}

Gerson (1994) states that the customer satisfaction is the customers' perception that his or her expectations are met or surpassed. In other words, according to Kotler and Clarke (1987) satisfaction is a state which is felt when a person has performance, experience or an outcome that meets her or his expectation. When a customer's expectations are met or exceeded by a product or service, the customer is generally satisfied. It is evident about the satisfaction that customers normally appreciate the services and goods if they feel special after purchasing.

One of the critical issues in the success of any business system is the customer satisfaction. Today's market conditions require that any organization wants to be successful; it must be customer-centered and give superior 
value to its customers. In establishing customer relationship organizations must be adept (Kotler et al., 2001). Satisfaction is considered as a central concept in marketing (Oliver, 1997). Customer satisfaction is generally the most efficient and the least expensive source of market communication since the satisfied customers usually spread their positive thoughts to other customers. Otherwise, they will disseminate negative appraisal if they are dissatisfied (Dubroski, 2001). Management of institutions must care the customer satisfaction if they want to survive. Customers are very important for successful business and they keep companies in existence. The satisfied customers repeat the purchase of the product or service and give positive messages about it to others. On the other hand, the dissatisfied customers look for different alternatives. Therefore, the basic and significant role of any business is to fulfill the expectation and needs of its customer. The message is clear that business is improved by the satisfied customers and it is impaired by the dissatisfied customers (Anderson \& Zemke, 1998).

Satisfaction is the result of the study of an organization's administration as well as educational system's consistent performance (Zeithaml, 1988). Winn and Green (1998) state that the most important customers are the parents of students in primary school. Parent satisfaction depends on different experiences of parents about school. Meeting the parents' expectations is considered to be necessary for creating customer satisfaction (Olson, 1999). It is expected that more participated parents in school activities are more satisfied. Also, it is expected that the parents of successful students are more satisfied than the parents of less successful students (Himmelstein et al., 1991). Some aspects of schools such as teachers, employees and cafeteria have effect on the parent satisfaction. The satisfied parents feel better and informed about their children's school activities. They believe that their children are safe in the school and think that the school values their involvement. The dissatisfied parents can change easily their school decisions. Therefore, they can send their children to private schools or they can move to different school areas. Increasing satisfaction of parents is thought one way of developing the quality of the schools (Salisbury et al., 1997).

\section{Service Quality}

Generally, there are many definitions for quality. Pariseau and McDaniel (1997) define that quality is excellence, quality is value, and quality is conformance to specifications. According to Juran and Gryna (1988), quality is fitness for use. Some other definitions are given as follows. Quality is conformance to requirements (Crosby, 1979). Quality is meeting and / or exceeding customers' expectations (Parasuraman et al., 1985). These common definitions underline the relationship between quality and the need of customer and satisfaction (Zafiropoulos et al., 2005).

In service industries service quality is arisen important attention and discussion in the research literature because of the difficulties in both defining it and measuring it with no overall consensus emerging on either (Wisniewski, 2001). Organizations evaluate service quality as key strategic value in both service and manufacturing sectors (Rashid \& Jusoff, 2009). There are different definitions for service quality. Parasuraman et al. (1988) mention that service quality is customer behavior projecting the perceived whole superiority and excellence in the process and outcome of a service provider. Asubonteng et al. (1996) define service quality as the degree to which a service meets customers' needs or expectations. The gap between customer expectation and perception about service can be defined as service quality. If the performance is less than expectations then perceived quality is low and customer dissatisfaction is seen (Parasuraman et al., 1985). Gronross (1984) highlights that perceived service quality occurs when the customers compare their expectations with their perceptions of actual service and it is a universal judgment or attitude which is related to service performance.

Arambewela and Hall (2009) claim that the fundamental notion of quality is simply the match between what customers experience and what they expect. This is perceived quality and any mismatch between them is a quality gap. Customer perception of quality is influenced by different gaps. For increasing service quality level, it is the first step to understand customer perceptions and expectations (Zeithaml \& Bitner, 2002).

The above mentioned common features about the service quality are valid for the education sector. Moreover, it has some different characteristics. The most important of these features is the decision making. In primary education, parents are the main decision maker rather than the students. Hence, parents constitute the customer focus of primary education (Kuruzm, 2001). Service quality has a significant role in education. Increasing the educational service quality is a universal agenda at all educational levels like primary education. Fundamental education's quality is considerable because of that it is not only training students for the next educational step, but also equipping them for the life with necessary main skills. Lockheed and Verspoor (1991) identify that educational output has different inputs and process determinants. They cover curriculum, school environment, qualified teachers, learning materials like textbooks, effective use of school time, time for learning and healthy children. 
To increase the quality level, the key determinants of service quality have to be determined. Parasuraman et al. (1988) state that there are 5 key determinants of perceived service quality. The 5 dimensions and the descriptions the authors give are listed below:

- Reliability: Capability to do the promised service accurately and dependably.

- Tangibility: Physical properties, appearance of personnel and equipment.

- Responsiveness: Voluntariness to help customers and provide immediate service.

- Assurance: Kindness and knowledge of staff and their capability to inspire confidence and trust.

- Empathy: Caring, individualized interest the firm provides to its customers.

Researches in measuring and defining service quality have been affected very much by the study of Parasuraman et al. $(1985 ; 1988)$. A scale called SERVQUAL is developed by these authors based on the above factors. According to this model, customers evaluate the service quality by comparison of actual service with desired service. Consumers fundamentally use the same criteria to evaluate quality. Service quality is a general opinion the user forms regarding its delivery that is constituted by a series of successful or unsuccessful experiences (Parasuraman et al., 1985; 1988).

\section{Research Framework and Methodology}

From the review of literature, it is obvious that there are two variables which are suitable for this study. The dependent variable is parent (customer) satisfaction in primary education. The independent variables are given as the dimensions that impact service quality level. They are tangibility, reliability, responsiveness, assurance and empathy. This paper attempts to investigate the effect of the dimensions of service quality on parent satisfaction in primary education. The framework of this research stating the independent and dependent variables is given in Figure 1.

\section{Independent Variables}

\section{Dependent Variable}

Service Quality Dimensions

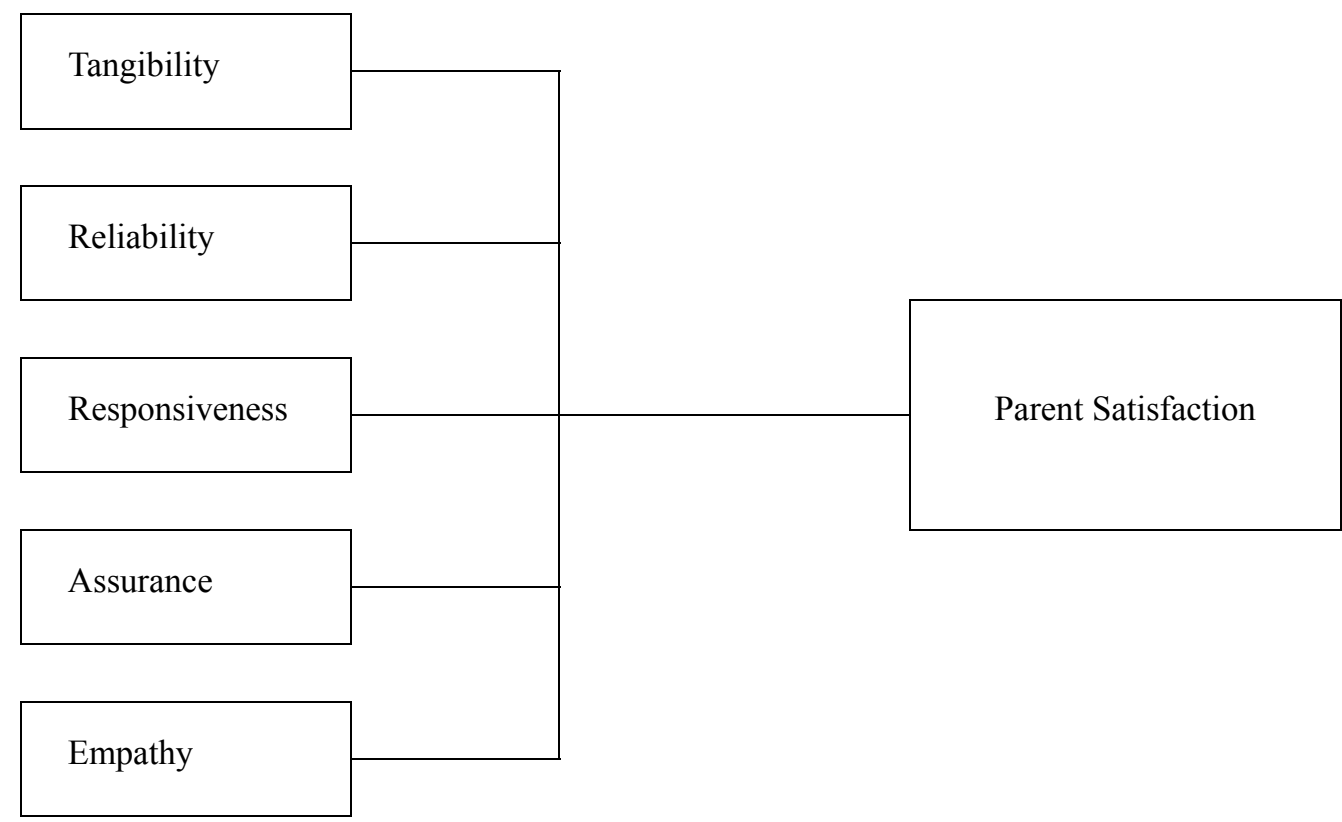

Figure 1. Framework of the research

According to the objectives of the study and the literature review, the following hypotheses are formulated:

H1: Tangibility has a significant effect on parent satisfaction.

H2: Reliability has a significant effect on parent satisfaction.

H3: Responsiveness has a significant effect on parent satisfaction. 
H4: Assurance has a significant effect on parent satisfaction.

H5: Empathy has a significant effect on parent satisfaction.

This study is designed to assess service quality in primary school and gain better understanding of the parents' satisfaction toward the service quality in primary education. Thus, the study favors a quantitative research perspective. The study utilizes a relational research design in an effort to examine and measure the effect of the service quality on parents satisfaction level. The target population is mainly the parents from Celal Avşar Primary School in Turkey.

Data is collected by means of a self-administered questionnaire which is distributed to 400 parents of students of Celal Avşar Primary School during the academic session 2011/2012. The required data is collected with the help of the teachers and students of the school. A total of 293 acceptable questionnaires are received with a response rate of $73.25 \%$ which is considered as acceptable. The data is analyzed through the use of a package program called the Statistical Package for Social Sciences (SPSS) version 18. The questionnaire composed of five SERVQUAL dimensions is used from Pariseau and McDaniel (1997), in which the language adjustment is made in order to fit in the academic environment. It contains 22 statements covering five determinants namely; tangibility, reliability, responsiveness, assurance and empathy. The second part of the questionnaire consists of 6 items on parent satisfaction level. The parent satisfaction items are adapted from Atheeyaman (1997). The five-point Likert scale ranging from 1 (strongly disagree) to 5 (strongly agree) is used for this purpose. The third part of the questionnaire consists of 4 items for demographic data about the respondents.

\section{Findings and Discussions}

According to the results of the study, 40 (13.7\%) of respondents are male and $253(86.3 \%)$ are female. $16(5.5 \%)$ respondents are between the ages of 20-29 years, 173 (59.0\%) respondents between the ages of 30-39, whereas $99(33.8 \%)$ respondents are between the ages of $40-49$, and $5(1.7 \%)$ respondents are more than 50 years old. 33 $(11.3 \%)$ of respondents are the parents of first-year students, $49(16.7 \%)$ of respondents are the parents of second-year students, $37(12.6 \%)$ of respondents are the parents of third-year students, $39(13.3 \%)$ of respondents are the parents of forth-year students, $37(12.6 \%)$ of respondents are the parents of fifth-year students, $37(12.6 \%)$ of respondents are the parents of sixth-year students, $25(8.5 \%)$ of respondents are the parents of seventh-year students and $36(12.3 \%)$ of respondents are the parents of eighth-year students. 114 (38.9\%) respondents have primary school education, 132 (45.1\%) respondents have high school education, 42 $(14.3 \%)$ respondents have university education, $4(1.4 \%)$ respondents have master degree education and $1(0.3 \%)$ respondent has doctorate or higher education degree. Cronbach alpha scores are used to test the reliability of the SERVQUAL dimensions. The values are given in Table 1. All the dimensions have high alpha scores in most cases exceeding 0.70 with the exception of responsiveness, which has a value of 0.622 . The reliability analysis indicates that the SERVQUAL scale used to measure parent's perceptions of education service quality is statistically reliable.

Table 1. Reliability statistics

\begin{tabular}{lc}
\hline Dimensions & Cronbach $\alpha$ \\
\hline Tangibility & 0.792 \\
Reliability & 0.827 \\
Responsiveness & 0.622 \\
Assurance & 0.705 \\
Empathy & 0.837 \\
Parent Satisfaction & 0.843 \\
\hline
\end{tabular}

Regression analysis is performed between parent satisfaction and service quality dimensions (empathy, responsiveness, assurance, tangibility, and reliability). The main results of the model are given in Table 2. According to Table 2, the coefficient of determination $\mathrm{R}^{2}$ is 0.494 which means that $49.4 \%$ of parent satisfaction variation is explained by the dimensions. The remaining $50.6 \%$ of the variation is identified by other factors not captured in the model. The ANOVA analysis related to the regression model is performed and the results are given in Table 3. According to Table 3, the significance value of the analysis is $0.000<0.05$ which means that the 
dependent variable can be explained by the independent variables at $95 \%$ confidence level. After this examination, the detailed information about the regression analysis which includes the coefficients of independent variables, their test statistics and the collinearity statistics is given in Table 4. According to Table 4, four independent variables namely; tangibility, reliability, assurance, and empathy are significant at the $95 \%$ confidence level. That means these variables are positively significant with parent satisfaction. There is only one independent variable (responsiveness) which is not significant (sig. level $=0.861>0.05$ ).

Table 2. Model summary

\begin{tabular}{ccccc}
\hline $\mathrm{R}$ & $\mathrm{R}$ Square & Adjusted R Square & Std. Error of the Estimate & Durbin-Watson \\
\hline 0.703 & 0.494 & 0.485 & 0.524 & 2.028 \\
\hline
\end{tabular}

a. Predictors: (Constant), Empathy, Reliability, Responsiveness, Tangibility, Security

b. Dependent Variable: Satisfaction

Table 3. Results of ANOVA analysis

\begin{tabular}{lccccc}
\hline & Sum of Squares & df & Mean Square & F & Sig. \\
\hline Regression & 76.947 & 5 & 15.389 & 56.044 & 0.000 \\
Residual & 78.808 & 287 & 0.275 & & \\
Total & 155.755 & 292 & & & \\
\hline
\end{tabular}

a. Predictors: (Constant), Empathy, Reliability, Responsiveness, Tangibility, Assurance

b. Dependent Variable: Satisfaction

Table 4. The results of regression analysis

\begin{tabular}{lccccccc}
\hline & \multicolumn{2}{c}{$\begin{array}{c}\text { Unstandardized } \\
\text { Coefficients }\end{array}$} & $\begin{array}{c}\text { Standardized } \\
\text { Coefficients }\end{array}$ & & & \multicolumn{2}{c}{ Collinearity Statistics } \\
\hline & $\mathrm{B}$ & Std. Error & Beta & $\mathrm{t}$ & Sig. & Tolerance & VIF \\
\hline (Constant) & -0.210 & 0.308 & & -0.683 & 0.495 & & \\
Tangibility & 0.275 & 0.065 & 0.246 & 4.255 & 0.000 & 0.526 & 1.901 \\
Reliability & 0.141 & 0.052 & 0.118 & 2.727 & 0.007 & 0.943 & 1.061 \\
Responsiveness & 0.011 & 0.061 & 0.009 & 0.176 & 0.861 & 0.642 & 1.557 \\
Assurance & 0.278 & 0.082 & 0.219 & 3.390 & 0.001 & 0.424 & 2.360 \\
Empathy & 0.364 & 0.065 & 0.347 & 5.579 & 0.000 & 0.455 & 2.196 \\
\hline
\end{tabular}

a. Dependent Variable: Satisfaction

The assumptions of the regression model related to residuals are examined for the validity of the analysis. The residual plots are examined, but they are not given here. According to the plots, there is no problem for homoscedasticity and normality. It can be seen in Table 2 that the residuals are not correlated since the Durbin-Watson statistics is equal to nearly two. The other assumption which has to be examined is multicollinearity. According to Table 4, Variance Inflation Factor (VIF) scores for each independent variable 1.901 for tangibility, 1.061 for reliability, 1.557 for responsiveness, 2.360 for assurance and 2.196 for empathy are lower than 10. Therefore, it can be assumed that there is no strong linear relationship among these variables. As a result, it can be said that the assumptions are satisfied for the regression model.

The average level of service quality at the primary school of Turkey relating to the various dimensions registered a mean scores of 4.1553 (Assurance), 4.0154 (Tangibility), 3.9809 (Empathy), 3.4778 (Responsiveness), and 2.9345 (Reliability). Given the average scores of the five dimensions of service quality, it appears that the score for reliability is lower than responsiveness, followed by empathy, tangibility, and assurance which has higher scores. These results suggest the need to have more improvement in the reliability than others, because it has 
lower mean score than others. Also it can be seen that there is the need to have improvement in the assurance, tangibility, responsiveness and empathy.

This study shows that empathy has a significant effect on parent's satisfaction level in the parents' perception of service quality rendered by the school. The finding indicates that personal care and individualized attention to the students and parents are important factors impacting parents' satisfaction. This study also shows that assurance has a significant effect on parent's satisfaction level in the parents' perception of service quality rendered by the school. It is seen in the findings parents give importance that staff or teachers are polite and trustable. In the same way, the current study shows that there is a significant effect of tangibility on parents' satisfaction perceptions. The possible explanation of this finding is that parents appreciate the provision of equipment, teaching materials, and other physical evidences by school staff. Also, reliability seems to have a significant effect on the parent's satisfaction in the parents' perception of service quality rendered by the school. Reliability and consistency are important for the parents to increase their satisfaction level. On the other hand, there is no significant effect of responsiveness on parents' satisfaction in the parents' perception of service quality rendered by the school. This is probably due to the policy pursued by the school where all queries need to be responded to appropriately and promptly. Thus, the question of responsiveness or promptness of service related to the parent's satisfaction does not arise in the minds of the parents.

\section{Conclusion}

This study focuses on the issue of service quality and parent satisfaction in a primary education. It attempts to determine if there is any effect of service quality on parent's satisfaction, providing important information for the understanding of service quality in primary education sector in Turkey. It is quite evident that service quality has significant positive effect on parent satisfaction. Thus, parents' satisfaction level can be enhanced by improving the service quality. According to the regression analysis, it is evident that four dimensions in service quality namely; tangibility, reliability, empathy and assurance are the critical factors in explaining parents' satisfaction. Whatever done to increase tangibility, reliability, empathy and assurance in service quality will help parents to give a better evaluation of their satisfaction.

One of the limitations in this study is that the context of respondents is very limited to only one public primary school. The study can be expanded to include other public and private primary schools to establish competitive benchmarks by evaluating service quality and parent satisfaction as further studies. Also, new studies can be done at the primary school to observe the long-term implications of service quality improvement efforts by using the same methodology.

\section{Acknowledgement}

The authors are grateful Ömer Perçin (School Manager) and Saime İncesu (Teacher) for their supports and helps. The authors thank to all participants for their involvement and feedback. Also, the helpful comments of the anonymous referee are gratefully acknowledged.

\section{References}

Anderson, E. W., Fornell, C., \& Lehmann, D. R. (1994). Customer Satisfaction, Market Share and Profitability: Findings from Sweden. Journal of Marketing, 58(3), 53-66. http://dx.doi.org/10.2307/1252310

Anderson, K., \& Zemke, R. (1998). Delivering Knock Your Socks off Service. New York: Amacom.

Arambewela, R., \& Hall, J. (2009). An empirical model of international student satisfaction. Asian Pacific Journal of Marketing and Logistics, 21(4), 555-569. http://dx.doi.org/10.1108/13555850910997599

Asubonteng, P., Mccleary, K. J., \& Swan, J. E. (1996). SERVQUAL revisited: a critical review of service quality. The Journal of Services Marketing, 10(6), 62-81. http://dx.doi.org/10.1108/08876049610148602

Atheeyaman, A. (1997). Linking student satisfaction and service quality perceptions: the case of university education. European Journal of Marketing, 31(7), 528-540. http://dx.doi.org/10.1108/03090569710176655

Crosby, P. B. (1979). Quality is Free. New York: McGraw Hill.

Dubroski, D. (2001). The role of customer satisfaction in achieving business excellence. Total Quality Management, 12(7), 920-925. http://dx.doi.org/10.1080/09544120100000016

Gerson, R. F. (1994). Measuring Customer Satisfaction (1st ed.). Crisp Learning.

Gronross, C. (1984). A service quality model and its marketing implications. European Journal of Marketing, 
18(4), 36-44. http://dx.doi.org/10.1108/EUM0000000004784

Himmelstein, S., Graham, S., \& Weiner, B. (1991). An attributional analysis of maternal beliefs about the importance of child-rearing practices. Child Development, 62(2), 301-311. http://dx.doi.org/10.1111/j.1467-8624.1991.tb01532.x

Juran, J. M., \& Gryna, F. M. (1988). Juran's Quality Control Handbook. New York: McGraw-Hill.

Kotler, P., \& Clarke, R. N. (1987). Marketing for Health Care Organizations. Englewood Cliffs, NJ: Prentice-Hall.

Kotler, P., Armstrong, G., Saunders, J., \& Wong, V. (2001). Principle of Marketing (3rd ed.). Prentice Hall.

Kuruzm, A. (2001). A maximization model to satisfy the perceived quality in education. METU Studies in Development, 28(2), 127-141.

Lee, M. C., \& Hwan, I. S. (2005). Relationships among Service Quality, Customer Satisfaction and Profitability in the Taiwanese Banking Industry. International Journal of Management, 22(4), 635-648.

Lockheed, M. E., \& Verspoor, A. M. (1991). Improving primary education in developing countries. Oxford University Press for the World Bank.

Oliver, R. L. (1997). Satisfaction: A Behavioral Perspective on the Consumer. New York: McGraw-Hill.

Olson, L. (1999). ETS Analysis Tracks Parent Dissatisfaction. Education Week, XIX(9).

Parasuraman, A., Zeithaml V. A., \& Berry L. L. (1988). Servqual: A multiple-item scale for measuring consumer perceptions of service quality. Journal of Retailing, 64(1), 12-40.

Parasuraman, A., Zeithaml, V. A., \& Berry, L. L. (1985). A conceptual model of service quality and its implications for future research. Journal of Marketing, 49(4), 41-50. http://dx.doi.org/10.2307/1251430

Pariseau, S., \& McDaniel, J. R. (1997). Assessing service quality in schools of business. International Journal of Quality and Reliability Management, 14(3), 204-218. http://dx.doi.org/10.1108/02656719710165455

Pederson, S., \& Wilk, S. (1993). Iowa behavioral initiative: How can schools better serve students with behavioral needs? What families have to say: A survey report.

Rashid, W., \& Jusoff. H. (2009). Service quality in health care setting. International Journal of Health Care Quality Assurance, 22(5), 471-482. http://dx.doi.org/10.1108/09526860910975580

Salisbury, D. F., Branson, R. K., Altreche, W. I., Funk, F. F., \& Broetzmann, S. M. (1997). Applying customer dissatisfaction measures to schools: you better know what's wrong before you try to fix it. Educational Policy, 11(3), 286-308. http://dx.doi.org/10.1177/0895904897011003002

Ugboma, C., Ogwude, I. C., Ugboma, O., \& Nadi, K. (2007). Service quality and Satisfaction Measurements in Nigerian Ports: An Exploration. Maritime Policy and Management, 34(4), 331-346. http://dx.doi.org/10.1080/03088830701539073

Winn, R. C., \& Green R. S. (1998). Applying Total Quality Management to the Educational Process. International Journal of Engineering Education, 14(1), 24-29.

Wisniewski, M. (2001). Using SERVQUAL to assess customer satisfaction with public sector services. Managing Service Quality, 11(6), 380-388. http://dx.doi.org/10.1108/EUM0000000006279

Zafiropoulos, C., Fragidis, G., Kehris, E., Dimitriadis, S., \& Paschaloudis, D. (2005). Service quality assessment in higher education, the case of Technological Educational Institute (T.E.I.) of Serres, Greece. In 9th International Conference on Marketing and Development: Marketing Contributions to Prosperity and Peace, Thessaloniki, Greece, June 8-11.

Zeithaml, V. A. (1988). Consumer perceptions of price, quality, and value: a means-end model and synthesis of evidence. Journal of Marketing, 52(3), 2-22. http://dx.doi.org/10.2307/1251446

Zeithaml, V., \& Bitner, M. (2002). Services Marketing (3rd ed.). New York: McGrawHill. 